Boston University School of Law

Scholarly Commons at Boston University School of Law

Faculty Scholarship

1990

\title{
The Influence of Litigation Costs on Deterrence Under Strict Liability and Under Negligence
}

Keith N. Hylton

Boston University School of Law

Follow this and additional works at: https://scholarship.law.bu.edu/faculty_scholarship

Part of the Litigation Commons

\section{Recommended Citation}

Keith N. Hylton, The Influence of Litigation Costs on Deterrence Under Strict Liability and Under Negligence, in 10 International Review of Law and Economics 161 (1990).

Available at: https://scholarship.law.bu.edu/faculty_scholarship/1016

This Article is brought to you for free and open access by Scholarly Commons at Boston University School of Law. It has been accepted for inclusion in Faculty Scholarship by an authorized administrator of Scholarly Commons at Boston University School of Law. For more information, please contact lawlessa@bu.edu. 


\title{
THE INFLUENCE OF LITIGATION COSTS ON DETERRENCE UNDER STRICT LIABILITY AND UNDER NEGLIGENCE
}

\author{
KEITH N. HYLTON \\ Assistant Professor, Northwestern University School of Law, and Research \\ Fellow, American Bar Foundation, USA
}

\section{INTRODUCTION}

This paper examines the influence of litigation costs on deterrence under strict liability and under negligence. By deterrence, I refer to the effect of the threat of liability on the care exercised by potential injurers. ${ }^{1}$ More precisely, this paper takes litigation costs as given and examines the social desirability of the levels of care exercised under negligence and under strict liability.?

The relationship of this paper to the existing literature examining the influence of litigation costs on incentives under a liability system can best be described by comparing its focus to two fairly recent papers. ${ }^{3}$ Shavell (1982) examines whether plaintiffs bring suit when bringing suit is socially desirable in a regime in which litigation is costly. Polinsky and Rubinfeld (1988) examine whether the level of liability is socially optimal in a regime in which litigation is costly. This paper examines whether the level of care is socially optimal in a regime in which litigation is costly.

The major result presented in this paper is that strict liability leads to underdeterrence when litigation costs are taken into account. The intuition behind this conclusion is straightforward. Optimal deterrence requires that all external costs resulting from the injurer's failure to take care be "internalized" to the injurer. But if litigation is costly, two types of external cost will not be internalized under strict liability: the litigation cost "imposed" on victims who choose to sue; and the losses suffered by victims who choose not to sue because the cost of litigating exceeds the anticipated damage award.

The negligence rule also leads to underdeterrence when litigation costs are taken into account. Specifically, if agents have rational expectations and the jury is perfectly informed, then in equilibrium a negligence regime must underdeter. The

I thank Steven Shavell for many valuable discussions. I also thank Ian Ayres, Richard Craswell, John Donohue, Daniel Rubinfeld, Peter Siegelman, and an anonymous referee for helpful comments on this paper. I have benefited from the support of the Program in Law and Economics at Harvard Law School, which is itself supported by a grant from the John M. Olin Foundation.

'This paper does not discuss the level of care exercised by potential victims, nor does it address the activity levels of injurers or victims.

${ }^{2}$ The socially optimal level of care is the level that minimizes the sum of expected accident losses, the cost of accident avoidance, and litigation costs. "Optimal deterrence" results when actors take care when and only when it is socially desirable.

${ }^{3}$ On the influence of litigation costs on incentives see, e.g., Ordover (1978), Ordover (1981), Shavell (1982), Menell (1983), Kaplow (1986), Rose-Ackerman and Geistfeld (1987), Polinsky and Rubinfeld (1988). 
reason for this was, for the most part, provided in Ordover (1978): if under negligence all injurers obey the due care standard, no one will have an incentive to sue because the expected award will be zero; and if no one will sue, no one has an incentive to take care. Thus, an equilibrium under negligence requires the presence of a subset of potential injurers who do not obey the due care standard. It is shown in this paper that this subset is made up of potential injurers for whom taking care is socially desirable; thus, negligence underdeters.

Part A of section 2 of this paper presents the model. Part B of the same section presents the basic deterrence proposition under strict liability and discusses implications of the model for the literature on the social versus private incentives to bring suit. ${ }^{4}$ Part $\mathrm{C}$ discusses deterrence under negligence.

\section{THE MODEL}

\section{A. Basic structure and assumptions}

All actors are assumed to be risk neutral. It is also assumed that victims (plaintiffs) are the only parties who suffer loss from an accident, that the risk of loss to victims can be reduced by the exercise of caution by potential injurers (potential defendants), and that it is costly for injurers to take care.

Let $p=$ the probability of loss if potential injurers do not take care, $p>0$; and $\mathrm{q}=$ the probability of loss if injurers do take care, $\mathrm{p}>\mathrm{q}>0$. Let $\mathrm{v}-$ the (dollar) loss suffered by an accident victim, $v>0$. The variable $v$ is assumed to be random, with distribution function $H(v)$. Specifically, it is assumed that the potential injurer randomly cxperiences accidents with victims, each of whom is capable of realizing a specific dollar loss, and these losses are distributed over the population in accordance with the distribution function $\mathrm{H} .{ }^{5}$ Thus, if the potential injurer takes care, the expected loss suffered by victims is $q E(v)$; and if the injurer does not take care the expected loss is $\mathrm{pE}(\mathrm{v})$, where

$$
E(v)=\int_{0}^{\infty} v d H(v)
$$

Let $x=$ the cost to a potential injurer of taking care, where $x>0$. The variable $x$ is assumed to be random, with distribution function $G(x)$. The value of $x$ is unobservable to potential victims; however, it is observed by the injurer and is known to him before he commits an offense. Further, in a negligence regime in which jurors have perfect information, the value of $\mathrm{x}$ is, in effect, observed by the jury. The typical injurer will choose not to take care if the expected cost of taking care exceeds the expected cost of not doing so. Thus unlcss the injurcr is required to pay damages for either committing an offense or failing to take care, precaution will not be exercised.

I assume that victims can sue for no more than the value of their loss, $v .{ }^{6}$ Let $c_{\mathrm{v}}=$ the litigation cost borne by a victim, $\mathrm{c}_{\mathrm{v}}>0$; and $\mathrm{c}_{\mathrm{o}}=$ the litigation cost borne by an injurer in defending himself against a claim, $c_{o}>0$.

${ }^{4}$ See Shavell (1982), Menell (1983), Kaplow (1986), Rose-Ackerman and Geistfeld (1987). ${ }^{5}$ An alternative explanation is that the accident loss imposed on every victim is itself a random variable governed by $\mathrm{H}(\mathrm{v})$.

${ }^{6}$ The assumption that victims generally can sue for no more than the loss from injury has a great deal of support. See McCormick (1935), p. 85. There are, of course, cases in which victims are awarded more than their losses (e.g., punitive damages, treble damages in antitrust). Conversely, there are examples in which suits are brought by the government but where victims are awarded damages (e.g., enforcement of the National Labor Relations Act). 


\section{B. Strict liability}

\section{Basic Propositions}

In this section I consider the influence of litigation costs on deterrence under strict liability.

Two basic assumptions determine the effect of litigation costs on deterrence. The first is that suit is brought when it is privately profitable, that is, when $v>$ $c_{v}$. Thus, once an accident has occurred, the probability that the victim will bring suit is $1-H\left(c_{v}\right)$. The second assumption is that a potential injurer will take care if, after observing $x$, the expected cost of doing so is less than the expected cost of not doing so. Under these assumptions, the injurer will take care, under strict liability, when

$$
\mathrm{x}+\mathrm{q}\left[1-\mathrm{H}\left(\mathrm{c}_{\mathrm{v}}\right)\right]\left[\mathrm{c}_{\mathrm{o}}+\mathrm{E}\left(\mathrm{v} \mid \mathrm{v}>\mathrm{c}_{\mathrm{v}}\right)\right]<\mathrm{p}\left[1-\mathrm{H}\left(\mathrm{c}_{\mathrm{v}}\right)\right]\left[\mathrm{c}_{\mathrm{o}}+\mathrm{E}\left(\mathrm{v} \mid \mathrm{v}>\mathrm{c}_{\mathrm{v}}\right)\right]
$$

where

$$
\mathrm{E}\left(\mathrm{v} \mid \mathrm{v}>\mathrm{c}_{\mathrm{v}}\right)=\int_{\mathrm{c}_{\mathrm{v}}}^{\infty} \mathrm{vdH}(\mathrm{v}) /\left[1-\mathrm{H}\left(\mathrm{c}_{\mathrm{v}}\right)\right]
$$

Note that $E\left(v \mid v>c_{v}\right)$ is the expectation of $v$ given that $v>c_{v}$. Thus, $c_{0}+E(v \mid v>$ $c_{v}$ ) is the injurer's expected liability given that the victim brings suit. Equivalently, (2) can be written

$$
x<(p-q)\left[1-H\left(c_{v}\right)\right]\left[E\left(v \mid v>c_{v}\right)+c_{o}\right]
$$

Taking care is socially desirable if, after the realization of $\mathrm{x}$,

$$
p E(v)+p\left[1-H\left(c_{v}\right)\right]\left(c_{o}+c_{v}\right)>x+q E(v)+q\left[1-H\left(c_{v}\right)\right]\left(c_{o}+c_{v}\right) .
$$

Note that (5) can be rewritten

$$
x<(p-q) E(v)+(p-q)\left[1-H\left(c_{v}\right)\right]\left(c_{o}+c_{v}\right) .
$$

If private enforcement (that is, the bringing of suits by plaintiffs) causes some actors for whom (5) is not satisfied to take care, then such enforcement "overdeters." Similarly, if there are actors, for whom (5) is satisfied, who do not take care, then there is an "underdeterrence" problem. Finally, "optimal deterrence" occurs when enforcement causes actors to take care if and only if (5) is satisfied. With this in mind, we can state the following:

Proposition 1: Strict liability underdeters.

The proof relies on (4) and (6). Using (4) and (6), strict liability underdeters if and only if

$$
\begin{array}{r}
(p-q) E(v)+(p-q)\left[1-H\left(c_{v}\right)\right]\left(c_{o}+c_{v}\right) \\
\quad>(p-q)\left[1-H\left(c_{v}\right)\right]\left[E\left(v \mid v>c_{v}\right)+c_{o}\right],
\end{array}
$$


or equivalently

$$
\mathrm{E}(\mathrm{v})+\left[1-\mathrm{H}\left(\mathrm{c}_{\mathrm{v}}\right)\right] \mathrm{c}_{\mathrm{v}}>\int_{\mathrm{c}_{\mathrm{v}}}^{\infty} \mathrm{vdH}
$$

However, from the definition of $E(v)$

$$
E(v)=\int_{0}^{c_{v}} v d H+\int_{c_{v}}^{\infty} v d H
$$

and the proposition follows.

Thus, if the socially optimal level of care is the level that minimizes the sum of expected accident losses, accident avoidance costs, and litigation costs, a strict liability regime will always result in potential injurers, as a group, taking too little care relative to the social optimum. More precisely, there will be potential injurers for whom taking care is socially desirable who will not take care. The intuition behind this result is straightforward. In a regime in which litigation is costly, the social cost generated by the injurer's failure to take care is the sum of the expected loss imposed on a victim and the litigation costs imposed on society. Only part of this social cost is internalized under strict liability: the expected loss imposed on a victim who will bring suit plus the litigation cost borne by the injurer. As a result, strict liability must underdeter.

The intuition behind proposition I suggests a policy for achieving the socially optimal level of care under a strict liability regime. Optimal deterrence can be achieved by making the injurer pay, in the form of a tax added to the injurer's litigation cost, the expected loss imposed on a non-suing victim, plus the victim's litigation cost. ${ }^{7}$ This argument is stated in a more rigorous fashion in the following proposition.

Proposition 2: Under strict liability, the socially optimal level of care is achieved by adding to the injurer's expected litigation cost the victim's expected litigation cost plus the expected loss suffered by non-suing victims.

To prove proposition 2 , let $t$ be a tax that is added to the injurer's cost of litigating. Given this, $(p-q)\left[1-H\left(c_{v}\right)\right] t$ is the marginal tax incurred by the potential injurer in failing to take care. Using (4) and (6), deterrence is optimal if and only if

$$
\begin{aligned}
(p-q) v+(p-q)\left[1-H\left(c_{v}\right)\right]\left(c_{o}+\right. & \left.c_{v}\right) \\
& =(p-q)\left[1-H\left(c_{v}\right)\right]\left[E\left(v \mid v>c_{v}\right)+c_{o}+t\right]
\end{aligned}
$$

The solution requires that $\mathrm{t}$ satisfy

$$
\int_{0}^{c_{v}} v d H+\left[1-H\left(c_{v}\right)\right] c_{v}=\left[1-H\left(c_{v}\right)\right] t
$$

where the term on the right-hand side of (7) is the expected tax, given that an

${ }^{7}$ I use the word "tax" because I have in mind a fee that is collected by some agency of the state. Note that if the tax were paid over to the victim, as if it were an alteration in the level of damages, the victim would have greater incentive to sue. 
accident has occurred. The terms on the left-hand side of (7) are, respectively, the expected loss imposed of non-suing victims and the expected cost to the victim of litigating, given that an accident has occurred.

An alternative way of stating proposition 2 is suggested by rewriting (7) as follows:

$$
\int_{0}^{c_{v}} v d H /\left[1-H\left(c_{v}\right)\right]+c_{v}=t
$$

Thus, optimal deterrence is achieved by making the injurer pay a tax, in addition to the cost of the injurer of litigating, that is equal to the sum of two terms: the expected loss of non-suing victims, divided by the probability that suit will be brought, and the victim's litigation cost.

This unambiguously upward adjustment in the injurer's liability should be compared with Polinsky and Rubinfeld (1988), which suggests that the optimal adjustment to compensatory damages might be positive or negative. The conclusion differs here largely because this paper examines a different question. The Polinsky and Rubinfeld paper determines the level of damages, to be paid to the victim, that minimizes the sum of expected accident losses, avoidance costs, and expected litigation costs. This paper, in proposition 2, determines the level of liability that causes the injurer to exercise the socially optimal level of care. The key difference between the approaches is that the adjustment to damages is a tax that is not transferred to the victim in this model, while the adjustment becomes part of the victim's award in the Polinsky and Rubinfeld paper. In addition, in the Polinsky and Rubinfeld paper, the injurer is able to preclude suit by exercising a level of care that makes it unprofitable for the victim to bring suit. The injurer cannot do this in this model because the decision to sue itself depends on a random event: whether the victim's loss exceeds the cost of litigating. ${ }^{8}$

\section{Implications of the Model for the Literature on the Social Desirability of Suit}

The treatment of the typical victim's loss as random, which this paper adds to the basic model developed in Shavell (1982), has interesting implications for the literature on the social desirability of suit. ${ }^{9}$ Nothing in the model disturbs Shavell's point that social and private incentives to bring suit differ. To see this, note that in the model presented here, suit is socially desirable, that is, suit should not be prohibited, if

$$
\begin{aligned}
\mathrm{pE}(\mathrm{v})>\mathrm{gs}_{\mathrm{s}}\left\{\mathrm{E}_{\mathrm{s}}(\mathrm{x})+\mathrm{q}\left[1-\mathrm{H}\left(\mathrm{c}_{\mathrm{v}}\right)\right]\left(\mathrm{c}_{\mathrm{o}}+\mathrm{c}_{\mathrm{v}}\right)\right. & +\mathrm{qE}(\mathrm{v})\} \\
& +\left(1-\mathrm{g}_{\mathrm{s}}\right)\left\{\mathrm{p}\left[1-\mathrm{H}\left(\mathrm{c}_{\mathrm{v}}\right)\right]\left(\mathrm{c}_{\mathrm{o}}+\mathrm{c}_{\mathrm{v}}\right)+\mathrm{pE}(\mathrm{v})\right\},
\end{aligned}
$$

where $\mathrm{g}_{\mathrm{s}}$ is the probability that a potential injurer will take care under strict liability (in order to reduce expected liability), ${ }^{10}$ and is given by

$$
g_{s}=\int_{0}^{(p-q)\left[1-H\left(c_{v}\right) H\left[E\left(v \mid v>c_{v}\right)+c_{o}\right\}\right.} d G(x),
$$

${ }^{8}$ I examine the implications of this model for the optimal level of damages in Appendix B. ${ }^{9}$ Shavell (1982), Menell (1983), Kaplow (1986), Rose-Ackerman and Geistfeld (1987).

${ }^{10}$ Note that this is the probability that the cost of taking care, $x$, satisfies (4). 
and $E_{s}(x)$ is the expectation of $x$ given that the potential injurer takes care under strict liability, and

$$
E_{s}(x)=\int_{0}^{(p-q)\left[1-H\left(c_{v}\right)\right]\left[E\left(v \mid v>c_{v}\right)+c_{o} l\right.} x d G(x) / g_{s}
$$

Thus, suit is socially desirable if

$$
g_{s}\left\{(p-q) E(v)-E_{s}(x)\right\}>\left\{g_{s} q+\left(1-g_{s}\right) p\right\}\left[1-H\left(c_{v}\right)\right]\left(c_{o}+c_{v}\right),
$$

which requires that the expected net gain from taking care exceeds the expected litigation costs imposed on society. The confirmation of Shavell's result concerning the divergence between social and private incentives to sue is completed by noting that the social desirability condition is not the same as the plaintiff's incentive condition $v>c_{v}$.

Although Shavell's incentive divergence theorem remains valid in the model presented here, treating the typical victim's loss as random does disturb some of the results presented in the Menell, Kaplow, and Rose-Ackerman and Geistfeld papers. For in the models discussed in these papers, the injurer's expected liability (damages plus the cost of litigating) increases discontinuously at the point where the victim's loss is equal to the victim's cost of litigating. No such discontinuity is observed in a model in which the typical victim's loss (which is his anticipated recovery from bringing suit) is random. Without this discontinuity the injurer's cost-benefit analysis no longer includes the option of precluding suit altogether by exercising a level of care that makes it unprofitable for the victim to bring suit. Moreover, under the assumption that the typical victim's loss is random one can show that at the point of deciding the level of care, the injurer's cost-benefit analysis is not the same as the social cost-benefit analysis.

Because it involves a more elaborate model and the introduction of new notation, the implications of the model presented here for the Menell, Kaplow, and Rose-Ackerman and Geistfeld papers are discussed in the appendix. The appendix presents a model in which the injurer's level of caution is a continuous variable that influences the amount of the victim's damages. I demonstrate that propositions 1 and 2 remain valid in the more general model. ${ }^{11}$

\section{Negligence}

Under negligence, suit is brought when $w v>c_{v}$, where $w=$ the probability that the jury will find the defendant negligent. Thus, in a negligence regime, the probability that suit will be brought after an accident has occurred is $1-\mathrm{H}\left(\mathrm{c}_{\mathrm{v}} / \mathrm{w}\right)$.

Under the "Hand Formula,",12 an actor is negligent if he fails to take care when $(\mathrm{p}-\mathrm{q}) \mathrm{E}(\mathrm{v})>\mathrm{x}$, which is the social desirability criterion for taking care when

\footnotetext{
${ }^{11}$ Rose-Ackerman and Geistfeld, on p. 488, show that, under the assumptions of their model, the injurer will produce more than the socially optimal level of output when lawsuits are permitted, provided that the injurer does not choose to produce at a level that precludes suit.

"I refer to the formula for negligence stated by Judge Learned IIand in United States $v$. Carroll Towing Co., 159 F.2d 169 (2d Cir. 1947). The version presented in the text compares the marginal social cost of care to its expected marginal social benefit, ignoring litigation costs.
} 
litigation is costless. ${ }^{13}$ Any actor for whom $(p-q) E(v)>x$ is "potentially negligent," in the sense that he will be held negligent if his failure to take care leads to an accident which is followed by a lawsuit. It is assumed that victims correctly perceive the probability of a negligence verdict, and thus are aware of the requirements of the Hand Formula.

With perfect information, the jury will find the injurer negligent if, and only if, $(p-q) E(v)>x$ is satisfied and the injurer did not take care.

If the potential defendant could be judged negligent by a jury, because $(p-q) E(v)>x$, he will take care when

$$
\mathrm{x}<\mathrm{p}\left[1-\mathrm{H}\left(\mathrm{c}_{\mathrm{v}} / \mathrm{w}\right)\right] \mathrm{E}\left(\mathrm{v} \mid \mathrm{v}>\mathrm{c}_{\mathrm{v}} / \mathrm{w}\right)+(\mathrm{p}-\mathrm{q})\left[1-\mathrm{H}\left(\mathrm{c}_{\mathrm{v}} / \mathrm{w}\right)\right] \mathrm{c}_{\mathrm{o}},
$$

where

$$
\mathrm{E}\left(\mathrm{v} \mid \mathrm{v}>\mathrm{c}_{\mathrm{v}} / \mathrm{w}\right)=\int_{\mathrm{c}_{\mathrm{v}} / \mathrm{w}}^{\infty} \mathrm{vdH}(\mathrm{v}) /\left[1-\mathrm{H}\left(\mathrm{c}_{\mathrm{v}} / \mathrm{w}\right)\right]
$$

Since the jury has perfect information and actors correctly perceive the likelihood of a negligence verdict, $w$ is equal to the probability that the injurer is negligent (that is, potentially negligent and fails to take care), given that an accident has occurred. Using Bayes' Theorem, that probability is expressed as follows: ${ }^{14}$

$$
w=p\left[g_{n} q+\left(1-g_{n}\right) p\right]^{-1} \int_{p\left[1-H\left(c_{v} / w\right)\right] E\left(v / v>c_{v} / w\right)+(p-q)\left(1-H\left(c_{v} / w\right) \mid c_{o}\right.}^{(p-q) E(v)} d G(x)
$$

where $g_{n}$ is the probability that a potential injurer will take care under negligence and is given by

$$
g_{n}=\int_{0}^{p\left[1-H\left(c_{v} / w\right)\right] E\left(v \mid v>c_{v} / w\right)+(p-q)\left[1-H\left(c_{v} / w\right)\right] c_{0}} d G(x) .
$$

${ }^{13}$ This criterion minimizes the sum of expected accident losses and accident avoidance costs. Because it fails to take litigation costs into account, it is not the social desirability criterion for care in a world in which litigation is costly. However, because it is the traditional test for negligence it may be of interest to some whether actors will behave negligently, as defined by the Hand Formula, under a negligence regime or under strict liability. Whether actors behave negligently under a negligence regime is addressed briefly in this section of the text. The question whether actors behave negligently under strict liability is answered by the following result:

Under strict liability, some potential injurers will act negligently if and only if

$$
\int_{0}^{c_{v}} \mathrm{vdH}>\left[1-H\left(c_{\mathrm{v}}\right)\right] \mathrm{c}_{\mathrm{o}} .
$$

If the inequality is reversed, then some potential injurers will take care even though their failure to do so would not result in a negligence verdict. If the inequality is replaced with $=$ then only those potential injurers who would be held negligent will take care.

The prouf of this statement mimics that for proposition 1. The statement requires at comparison of the defendant's expected litigation cost to the expected loss suffered by non-suing victims.

${ }^{14}$ If victims are rational, as assumed here, they will update their forccasts of the probability of a negligence verdict using the information that an accident has occurred. Thus, the rational forecast of the probability of a negligence verdict, given that an accident has occurred, will be greater than the probability that a potential injurer will act negligently. 
An equilibrium value for the probability of a negligence verdict satisfies (11). Plaintiffs will bring suit only if the probability of a negligence verdict is positive. However, (11) clearly implies that $w$ is positive, or equivalently plaintiffs will bring suit, if and only if

$$
(p-q) E(v)>p\left[1-H\left(c_{v} / w\right)\right] E\left(v \mid v>c_{v} / w\right)+(p-q)\left\lfloor 1-H\left(c_{v} / w\right)\right\rfloor c_{o} .
$$

But if (12) holds, then there will be potentially negligent injurers who fail to take care.

This confirms the fundamental result of Ordover (1978) that equilibrium in a negligence regime requires the presence of a subset of actors who refuse to obey the due care standard. The reason is the following: if under negligence, all potentially negligent actors (those for whom $(p-q) E(v)>x)$ take care, then no plaintiff will expect to win a lawsuit, so suit will not be brought. But if suit is not brought, no actor will have an incentive to take care. It follows that the rational expectations equilibrium under negligence is one in which there exists a group of injurers who are potentially negligent and fail to take care.

Given an equilibrium within a negligence regime, taking care is socially desirable if, after the realization of $x$,

$$
p E(v)+p\left[1-H\left(c_{v} / w\right)\right]\left(c_{o}+c_{v}\right)>x+q E(v)+q\left[1-H\left(c_{v} / w\right)\right]\left(c_{o}+c_{v}\right) .
$$

However, given that (12) holds in an equilibrium, the following condition must hold:

$$
\begin{aligned}
(p-q) E(v)+ & (p-q)\left[1-H\left(c_{v} / w\right)\right]\left(c_{o}+c_{v}\right) \\
& >p\left[1-H\left(c_{v} / w\right)\right] E\left(v / v>c_{v} / w\right)+(p-q)\left[1-H\left(c_{v} / w\right)\right] c_{o}
\end{aligned}
$$

Thus,

Proposition 3: In equilibrium, negligence underdeters.

In other words, in an equilibrium within a negligence regime in which litigation is costly, some injurers for whom taking care is socially desirable will not take care. The reason is that a plaintiff can expect to win an award in a negligence suit only if there exists a subset of potential injurers who fail to take care and whose cost of taking care is such that $(p-q) E(v)>x$. But if an injurer's cost of taking care satisfies $(\mathrm{p}-\mathrm{q}) \mathrm{E}(\mathrm{v})>\mathrm{x}$, then the injurer is certainly one for whom taking care is socially desirable under the condition stated in (13). The presence of such an injurer implies that negligence underdeters.

\section{CONCLUSION}

This paper examines the influence of litigation costs on deterrence under strict liability and under negligence. The primary result is that private enforcement under strict liability underdeters, in the sense that not every potential injurer for whom taking care is socially desirable will take care. In addition, if an equilibrium exists in a negligence regime, negligence also underdeters. This is a natural extension of the result of Ordover (1978) that equilibrium in a negligence regime requires the existence of a subset of actors who fail to obey the due care standard. 


\section{APPENDIX A}

In this section I discuss the implications of the model for the results presented in the Menell, Kaplow, and Rose-Ackerman and Geistfeld papers. Adopting notation similar to that in the Rose-Ackerman and Geistfeld paper, let

$\mathrm{z}=$ injurer's output, $0 \leq \mathrm{z}<\infty$;

$\mathrm{P}(\mathrm{z})=$ gross profits of injurer, $\mathrm{P}^{\prime}(0)>0, \mathrm{P}^{\prime \prime} \leq 0$;

$D(z)=$ gross damage to victim if an accident occurs, a random variable, $\mathrm{D}^{\prime} \geq 0, \mathrm{D}^{\prime \prime} \geq 0$.

Also, assume that the probability of an accident $=1$

Proposition A1: Strict liability underdeters.

Proof: The social optimum in output, $\mathrm{z}^{*}$, maximizes the function

$$
\begin{aligned}
& \mathrm{SB}(\mathrm{z})=\mathrm{P}(\mathrm{z})-\operatorname{Prob}\left[\mathrm{D}(\mathrm{z})>\mathrm{c}_{\mathrm{v}}\right]\left\{\mathrm{E}\left[\mathrm{D}(\mathrm{z}) \mid \mathrm{D}(\mathrm{z})>\mathrm{c}_{\mathrm{v}}\right]+\mathrm{c}_{\mathrm{o}}+\mathrm{c}_{\mathrm{v}}\right\} \\
& -\operatorname{Proh}\left[\mathrm{D}(\mathrm{z})<\mathrm{c}_{\mathrm{v}}\right] \mathrm{F}\left[\mathrm{D}(\mathrm{z}) \mid \mathrm{D}(\mathrm{z})<\mathrm{c}_{\mathrm{v}}\right] \text {. }
\end{aligned}
$$

The injurer's net profit function, which is maximized at $z^{* *}$, is

$$
R(z)=P(z)-\operatorname{Prob}\left[D(z)>c_{v}\right]\left\{E\left[D(z) \mid D(z)>c_{v}\right]+c_{o}\right\}
$$

This claim is proven by showing that $\mathrm{SB}^{\prime}(\mathrm{z})<0$ at $\mathrm{z}^{* *}$. If this is so, social welfare can be increased by the injurer producing less. Substituting in the first order condition for $R(z)$, note that

$$
\begin{aligned}
\mathrm{SB}^{\prime}\left(\mathrm{z}^{* *}\right)= & -\left\{\left(\mathrm{dProb}\left[\mathrm{D}\left(\mathrm{z}^{* *}\right)>\mathrm{c}_{\mathrm{v}}\right] / \mathrm{dz}\right) \mathrm{c}_{\mathrm{v}}\right. \\
& \left.+\left(\mathrm{dProb}\left[\mathrm{D}\left(\mathrm{z}^{* *}\right)<\mathrm{c}_{\mathrm{v}}\right] / \mathrm{dz}\right) \mathrm{E}\left[\mathrm{D}\left(\mathrm{z}^{* *}\right) \mid \mathrm{D}\left(\mathrm{z}^{* *}\right)<\mathrm{c}_{\mathrm{v}}\right]\right\} \\
& +\operatorname{Prob}\left[\mathrm{D}\left(\mathrm{z}^{* *}\right)<\mathrm{c}_{\mathrm{v}}\right]\left(\mathrm{dE}\left[\mathrm{D}\left(\mathrm{z}^{* *}\right) \mid \mathrm{D}\left(\mathrm{z}^{* *}\right)<\mathrm{c}_{\mathrm{v}}\right] / \mathrm{dz}\right)
\end{aligned}
$$

Using the fact that $\operatorname{dProb}\left[\mathrm{D}(\mathrm{z})>\mathrm{c}_{\mathrm{v}}\right] / \mathrm{dz}=-\mathrm{dProb}\left[\mathrm{D}(\mathrm{z})<\mathrm{c}_{\mathrm{v}}\right] / \mathrm{dz}$, this can be rewritten

$$
\begin{aligned}
\mathrm{SB}^{\prime}\left(\mathrm{z}^{* *}\right)=-\left\{\left(\mathrm { dProb } \left[\mathrm{D}\left(\mathrm{z}^{* *}\right)>\right.\right.\right. & \left.\left.\mathrm{c}_{\mathrm{v}}\right] / \mathrm{d} \mathrm{z}\right)\left(\mathrm{c}_{\mathrm{v}}-\mathrm{E}\left[\mathrm{D}\left(\mathrm{z}^{* *}\right) \mid \mathrm{D}\left(\mathrm{z}^{* *}\right)<\mathrm{c}_{\mathrm{v}}\right]\right) \\
& \left.+\operatorname{Prob}\left[\mathrm{D}\left(\mathrm{z}^{* *}\right)<\mathrm{c}_{\mathrm{v}}\right]\left(\mathrm{dE}\left[\mathrm{D}\left(\mathrm{z}^{* *}\right) \mid \mathrm{D}\left(\mathrm{z}^{* *}\right)<\mathrm{c}_{\mathrm{v}}\right] / \mathrm{dz}\right)\right\}
\end{aligned}
$$

which is negative.

Proposition A2: The optimal level of care is achieved by adding to the injurer's expected litigation cost the victim's expected litigation cost plus the expected loss imposed on non-suing victims.

Proof: The social optimum in care maximizes the function

$$
\begin{aligned}
\operatorname{SB}(z)= & P(z)-\operatorname{Prob}\left[D(z)>c_{v}\right]\{E[D(z) \mid D(z) \\
& \left.\left.>c_{v}\right]+c_{o}+c_{v}\right\} \\
& -\operatorname{Prob}\left[D(z)<c_{v}\right] E\left[D(z) \mid D(z)<c_{v}\right]
\end{aligned}
$$


Assuming that the injurer's cost of litigating is increased by $t$, the injurer's net profit function is

$$
R(z)=P(z)-\operatorname{Prob}\left[D(z)>c_{v}\right]\left\{E\left[D(z) \mid D(z)>c_{v}\right]+c_{o}+t\right\} .
$$

$S B(z)$ and $R(z)$ are equivalent if and only if

$$
\operatorname{Prob}\left[D(z)>c_{v}\right] t=\operatorname{Prob}\left[D(z)>c_{v}\right] c_{v}+\operatorname{Prob}\left[D(z)<c_{v}\right] E\left[D(z) \mid D(z)<c_{v}\right]
$$

and the proposition follows.

\section{APPENDIX B}

In this section I examine the implications of the model presented in this paper for the optimal level of liability. Following Polinsky and Rubinfeld (1988), let $\Delta=$ the adjustment to compensatory damages. Thus, under strict liability, the victim receives $v+\Delta$ if he sues the injurer.

The optimal adjustment to compensatory damages, $\Delta$, is chosen to maximize the net social benefit from private enforcement under strict liability, which is given by

$$
\operatorname{NSB}(\Delta)=g_{s}\left\{(p-q) E(v)-E_{s}(x)\right\}-\left\{g_{s} q+\left(1-g_{s}\right) p\right\}\left[1-H\left(c_{v}-\Delta\right)\right]\left(c_{o}+c_{v}\right),
$$

where

$$
g_{s}=\int_{0}^{(p-q)\left[1-H\left(c_{v}-\Delta\right)\right]\left[E\left(v \mid v>c_{v}-\Delta\right)+\Delta+c_{o}\right]} d G(x)
$$

and where

$$
E_{s}(x)=\int_{0}^{(p-q)\left[1-H\left(c_{v}-\Delta\right)\right]\left[E\left(v \mid v>c_{v}-\Delta\right)+\Delta+c_{o}\right]} x d G(x) / g_{s} .
$$

The derivative of NSB with respect to $\Delta$ is (suppressing the algebra)

$$
\begin{aligned}
\mathrm{dNSB} / \mathrm{d} \Delta= & \mathrm{g}_{\mathrm{s}}(\mathrm{p}-\mathrm{q})\left[\left(\mathrm{c}_{\mathrm{o}}+\mathrm{c}_{\mathrm{v}}\right) \mathrm{h}+1-\mathrm{H}\right]\{(\mathrm{p}-\mathrm{q}) \mathrm{E}(\mathrm{v}) \\
& +(\mathrm{p}-\mathrm{q})(1-\mathrm{H})\left(\mathrm{c}_{\mathrm{o}}+\mathrm{c}_{\mathrm{v}}\right) \\
& \left.-(\mathrm{p}-\mathrm{q})(1-\mathrm{H})\left[\mathrm{E}\left(\mathrm{v} \mid \mathrm{v}>\mathrm{c}_{\mathrm{v}}-\Delta\right)+\Delta+\mathrm{c}_{\mathrm{o}}\right]\right\} \\
& -\left[\mathrm{g}_{\mathrm{s}} \mathrm{q}+\left(1-\mathrm{g}_{\mathrm{s}}\right) \mathrm{p}\right]\left(\mathrm{c}_{\mathrm{o}}+\mathrm{c}_{\mathrm{v}}\right) \mathrm{h},
\end{aligned}
$$

where $\mathrm{H}=\mathrm{H}\left(\mathrm{c}_{\mathrm{v}}-\Delta\right)$ and $\mathrm{h}=\mathrm{H}^{\prime}$. This simplifies to

$\mathrm{dNSB} / \mathrm{d} \Delta=\mathrm{g}_{\mathrm{s}}(\mathrm{p}-\mathrm{q})(\mathrm{p}-\mathrm{q})\left[\left(\mathrm{c}_{\mathrm{o}}+\mathrm{c}_{\mathrm{v}}\right) \mathrm{h}+1-\mathrm{H}\right]\left[\mathrm{HE}\left(\mathrm{v} \mid \mathrm{v}<\mathrm{c}_{\mathrm{v}}-\Delta\right)\right.$

$$
\left.+(1-H)\left(c_{v}-\Delta\right)\right]-\left[g_{s} q+\left(1-g_{s}\right) p\right]\left(c_{o}+c_{v}\right) h \text {. }
$$

Suppose $\Delta=\mathrm{c}_{\mathrm{v}}$. Then $\mathrm{h}=\mathrm{H}=0$, so that $\mathrm{dNSB} / \mathrm{d} \Delta$ simplifies to $\mathrm{dNSB} / \mathrm{d} \Delta=\mathrm{g}_{\mathrm{s}}(\mathrm{p}-\mathrm{q})(\mathrm{p}-\mathrm{q})\left(\mathrm{c}_{\mathrm{v}}-\mathrm{c}_{\mathrm{v}}\right)=0$.

Suppose $\Delta>\mathrm{c}_{\mathrm{v}}$. Then, again, $\mathrm{h}=\mathrm{H}=0$, and the derivative simplifies to $\mathrm{dNSB} / \mathrm{d} \Delta=\mathrm{g}_{\mathrm{s}}(\mathrm{p}-\mathrm{q})(\mathrm{p}-\mathrm{q})\left(\mathrm{c}_{\mathrm{v}}-\Delta\right)<0$. 
Finally, suppose $\Delta<\mathrm{c}_{\mathrm{v}}$. Then the sign of the derivative is ambiguous, and depends on all of the factors summarized in the appendix of Polinsky and Rubinfeld (1988). Note that for $\Delta<\mathrm{c}_{\mathrm{v}}$, the first term in the derivative in (B2) is positive. This reflects deterrence benefits from increasing $\Delta$ : until $\Delta=\mathrm{c}_{\mathrm{v}}$, the injurer will exercise less than the socially optimal level of care. The second term in (B2) reflects the increase in litigation costs that results because with a higher level of liability more victims sue. For $\Delta<\mathrm{c}_{\mathrm{v}}$ the relevant question is whether the benefits from increasing care exceed the increased litigation costs that result from more victim suits.

Thus, as demonstrated in the Polinsky and Rubinfeld paper, the optimal adjustment to compensatory damages is generally ambiguous, because it depends on such factors as the productivity of care (in this model, the size of the difference between $p$ and $q$ ) and the total cost of litigation. If care is sufficiently productive, the derivative with respect to $\Delta$ of $\operatorname{NSB}(\Delta)$ will be positive for $\Delta<\mathrm{c}_{\mathrm{v}}$; thus, the adjustment which maximizes social welfare will be $\Delta^{*}=c_{\mathrm{v}}$. However, if the derivative of $\operatorname{NSB}(\Delta)$ is not positive for all $\Delta<c_{v}$ (say, because care is not "very productive"), the optimal adjustment may be at some point $\Delta^{*}$, where $\Delta^{*}<\mathrm{c}_{\mathrm{v}}$.

One result that emerges is that the optimal adjustment to compensatory damages will never exceed $c_{v}$, since net social benefit declines as $\Delta$ is increased above $c_{v}$. The reason is that once $\Delta=c_{v}$, all victims will sue, so that all external losses are "internalized" to the injurer. Increasing $\Delta$ beyond this point has no effect on the rate at which victims sue (because all victims will sue when $\Delta=c_{v}$ ), but causes injurers to exercise care beyond the socially optimal level.

\section{REFERENCES}

Kaplow, L. "Private Versus Social Costs in Bringing Suit," Journal of Legal Studies, 1986, vol. 15, 371-85.

McCormick, C. T. Handbook on the Law of Damages (1935).

Menell, P. S. "A Note on Private versus Social Incentives to Sue in a Costly Legal System," Journal of Legal Studies, 1983, vol. 12, 41-52.

Ordover, J. A. "Costly Litigation in the Model of Single Activity Accidents," Journal of Legal Studies, 1978, vol. 7, 243-61.

Ordover, J. A. "On the Consequences of Costly Litigation in the Model of Single Activity Accidents: Some New Results," Journal of Legal Studies, 1981, vol. 10, 269-91.

Polinsky, A. M. and D. L. Rubinfeld, "The Welfare Implications of Costly Litigation for the Level of Liability," Journal of Legal Studies, 1988, vol. 17, 151-64.

Rose-Ackerman, S. and M. Geistfeld, "The Divergence Between Social and Private Incentives to Sue: A Comment on Shavell, Menell, and Kaplow,"Journal of Legal Studies, 1987, vol. 16, 483-91.

Shavell, S. "The Social versus the Private Incentive to Bring Suit in a Costly Legal System," Journal of Legal Studies, 1982, vol. 11, 333-39. 